\section{SPOTLIGHT ON FLORA}

\section{Study identifies climate-resilient trees to help orangutans}

Indonesia's Kutai National Park, although severely degraded by human settlements and forest fires, supports one of the last intact forest canopies on Borneo's eastern coast, a habitat for the Critically Endangered East Bornean orangutan Pongo pygmaeus morio. To highlight the Park's conservation value and help ensure its long-term viability, an IUCN study analysed c. 250 species of native trees and other plants. The aim was to single out species resilient to the fires and drought conditions that are expected to become more frequent as a result of global warming, so that these could be used for restoration efforts. The researchers found that there are seven tree species that provide food and habitat for the orangutans, with two of these resilient to fire. The authors recommend these should be planted in buffer zones around fire-prone areas.

Source: Mongabay (2019) news.mongabay. com/2019/o3/study-identifies-climateresilient-trees-to-help-orangutanconservation

\section{Long-term monitoring closes data gaps in Himalayan forests}

Indian researchers have begun a long-term monitoring project of the Himalayan forest ecosystem and its sensitivity to climate change. They have set up six 1-ha areas in undisturbed forests in Pithoragarh district of Uttarakhand in the western Himalayas as geo-tagged permanent research plots, ranging from subtropical to subalpine habitat across an elevation of 1,000-3,800 m. Every 5 years these locations will be examined and changes will be mapped and analysed against baseline data collected in 2015 . Parameters monitored include forest, soil and socio-economic components that were chosen because they are influenced by climate change. Such long-term monitoring can address data deficiency associated with the overall Himalayan landscape. The project forms part of the Forest Resources and Plant Biodiversity theme of India's National Mission for Sustaining the Himalayan Ecosystem, which is tasked with the development of a robust database of flora and the long-term monitoring of the region's forests.

Source: Mongabay (2019) india.mongabay. com/2019/o3/researchers-initiate-longterm-monitoring-of-the-indian-himalayasto-aid-conservation
First multi-coloured rhododendron discovered in the Scottish Highlands. . Several rare species thrive in Wester Ross's historic Inverewe Gardens near Poolewe in Scotland, including various rhododendron hybrids, but gardeners were astonished to find what they believe is a unique multicoloured variety of the plant. Typically, the McCabe rhododendron Rhododendron macabeanum produces single-coloured trusses of flowers, but a new hybrid, dubbed Flora Pi Lo, flaunts an array of pastel shades from dusky pink to saffron yellow and ivory white. It is thought the warm waters of the Gulf Stream, combined with more sunshine and showers than normal, could be responsible for the creation of the rare variety. The gardening team at the National Trust property have taken cuttings from the new specimen, which are available for sale.

Source: The Press and Journal (2019) pressandjournal.co.uk/fp/news/highlands/ 1712686/worlds-first-multi-colouredrhododendron-has-been-discovered-inthe-highlands

\section{... and giant Taiwan cypresses found in southern Taiwan}

Approximately 100 giant Taiwan cypress trees Chamaecyparis formosensis were recently discovered in Taiwan's Central Moun-tain Range, with the largest trees measuring $15 \mathrm{~m}$ in circumference. These endemic trees were located in the Dapu Mountain area by a team from the Forestry Bureau's Taitung Forest District Office in December 2018 during an annual wildlife survey. The team surveyed the Shuang-guei Lake Major Wildlife Habitat, known for its diverse ecosystem comprising virgin forests that are home to c. 26 mammal and 86 bird species. The disclosure of the trees' locations raised concerns that it would encourage illegal logging given the timber's high market value (up to USD $39 / \mathrm{kg}$ ). However, the Office responded that logging would not be financially viable because of the trees' remote location, stressing that the best way to protect natural resources is to make their location public, thereby raising awareness and enabling everyone to monitor their status. Source: Focus Taiwan (2019) focustaiwan. tw/news/asoc/201901050006.aspx

\section{Rare plant given conservation boost by driving a tractor over it. .}

A tiny rare plant has been brought back from the brink with the help of an unusual conservation technique: running over it with a tractor. Marsh clubmoss Lycopodiella inundata is an ancient but highly threatened species which resembles a small spruce tree and is found on damp heathlands. It has declined by $85 \%$ in the past 85 years as its heath habitat has vanished because of development, tree plantations, agriculture and lack of habitat management, with only fragments remaining. It is now largely confined to a few strongholds in Dorset and Hampshire, UK. Marsh clubmoss thrives on bare wet ground created by disturbance such as grazing animals or tracks. The team's decision to deliberately drive over thousands of plants in a 5-t tractor paid off handsomely: where there were once 3,000 plants there is now a thriving colony of 12,000 growing in the heavily disturbed bare ground necklaced with pools created by tyre tracks.

Source: BT (2019) home.bt.com/news/uknews/rare-plant-given-conservation-boostby-driving-five-tonne-tractor-over-it11364332424386

\section{.. . and Pendine project in bid to bring rare orchid to firing range}

One of Britain's rarest orchids could soon be flowering on a military firing range. The internationally protected fen orchid Liparis loeselii grows in the wild in only two locations in the UK. Plantlife, a wildflower charity, is hoping to lure the orchid back to Pendine dunes, Carmarthenshire, 17 years after it disappeared from the area. A testing site for the armed forces may seem the last place for a dainty and protected flower, but work has begun to clear grasses and shrubs from Pendine dunes to restore the open sands and give the small wetland flower a chance to grow. The only other place in the UK where it grows in the wild are the fens of East Anglia. Although the clearing work will soon be complete at Pendine, orchids grow slowly, so it will take a few years before the flowers light up the dunes.

Source: BBC (2019) bbc.co.uk/news/ukwales-47333354

\section{Researchers rediscover supposedly extinct native plant using a drone}

Utilizing drone technology, researchers from the National Tropical Botanical Garden on Kauai have rediscovered a native Hawaiian plant that was thought to be extinct. Hibiscadelphus woodii was found in a small colony of three individuals growing on an 
inaccessible, vertical cliff face in a remote part of Kauai's Kalalau Valley. The rediscovery of $H$. woodii, categorized on the IUCN Red List as an extinct relative of hibiscus, provides a dramatic example of the growing importance of drones in conservation. Like other native Hawaiian species, $H$. woodii faces threats from invasive plants, introduced animals, and rock slides. Its rediscovery offers new hope that other species thought to be extinct may still survive in areas that are difficult to access.

Source: National Tropical Botanical Garden (2019) ntbg.org/news/researchers-redis cover-extinct-plant

\section{Using lichens in old-growth forests as an indicator of conservation value}

Canadian biologists have proposed an improved way to assess the conservation value of North American old-growth forests by using lichens, in acknowledgement of their role as sensitive bioindicators of environmental change. Old-growth forests are usually defined by tree age, with conservation and management practices developed accordingly, but new research argues that this approach overlooks the importance of biodiversity in those habitats. Lichens are ideal candidates to measure this biodiversity more directly, and are already used to assess forest continuity in parts of Europe. The study recommends increased focus on lichens for this purpose in North America, proposing that suites of lichens associated with known old-growth areas are used to develop an index of ecological continuity for forests of interest. This could then be used as a tool by conservation biologists and forest managers, reasoning that the more species recorded that are old-growth dependent, the higher the forest's conservation value. Source: Science Daily (2019) sciencedaily. com/releases/2019/03/190305083633.htm

\section{Aggressive African lovegrass disrupts Canberra's ecosystem}

An invasive grass is contaminating swathes of land in and around Canberra. The African lovegrass Eragrostis curvula can grow to $>1 \mathrm{~m}$ high and quickly dominates an area once it spreads. Because it grows in summer, it also raises fire risk and extends the fire season through the increased amount of dead, dry material in winter. The weed disrupts the ecosystem by displacing native grasses: as the original grasses disappear, the insect population that depends on them shrinks, which in turns leads to decreasing bird populations. The species was introduced to Australia in the 19th century as an import by misguided farmers who were unaware of the threats is poses to native biodiversity. Local conservation groups are trying to protect nature reserves and eradicate this invasive grass by mowing, spraying herbicides and raising awareness about how its seeds are spread. They hope the federal government will invest in researching a biological solution.

Source: Canberra Times (2019) canberratimes.com.au/story/5997113

\section{Ethiopia's first botanic garden opens, with a conservation agenda}

Ethiopia has recently opened its first botanic garden, aiming to make it a center of education, research and conservation. Located on 705 ha of land north of Ethiopia's capital Addis Ababa, Gulele Botanic Garden was opened to the general public in December 2018. The primary activity of the garden is conservation, followed by research on how to collect, propagate and reintroduce rare plants back to their natural habitats. The facility also supports practical education and ecotourism. With Ethiopia having five agro-ecological zones and $>6,500$ plant species, the garden will give priority to native and threatened plant species. Currently, it houses c. 700 indigenous and c. 65 Critically Endangered plant species. The garden is planning to expand its infrastructure, including plant laboratories, administrative buildings and greenhouses. Staff are also collaborating with plant researchers and botanic gardens outside Ethiopia, to increase conservation capacity. Source: News Ghana (2019) newsghana. com.gh/ethiopias-first-botanic-gardenopens-with-the-agenda-of-conservation

Mystery disease killing beech trees... A mysterious killer of beech trees is spreading across parts of the USA. The so-called beech leaf disease has been recorded in Ohio and Pennsylvania, and parts of Ontario, Canada. Scientists have yet to identify the tree killer or to halt its proliferation. The initial symptom is a dark staining pattern on the leaves, which is followed by the leaves becoming shrivelled and almost leathery in texture. Infected trees die over the course of a few years. Initial studies suggest there is no sign of insect infestation or the presence of other vectors. Several species of beech trees are vulnerable to the pathogen, which means the disease could reach beech trees in other parts of the world, such as the temperate biomes in Europe. Biosecurity is a key concern because the introduction or spread of the disease is probably a result of human activity. Source: BBC (2019) bbc.co.uk/news/ science-environment-47243317

\section{... and $60 \%$ of wild coffee species could go extinct}

A new pair of studies says up to $60 \%$ of wild coffee species could go extinct, some in the next 10-20 years, because of deforestation, human settlement, and climate change. There are 124 known species in the genus Coffea, but most of the beans used to make coffee come from domesticated versions of only two: C. arabica, which accounts for two-thirds of the global market, and C. canephora, which comprises the rest. However, arabica is especially susceptible to diseases, such as the devastating coffee leaf rust fungus, and arabica-canephora hybrids that were once resistant are beginning to succumb as well. Researchers at the Royal Botanical Gardens, Kew, UK, conducted the most comprehensive global coffee assessment to date, mapping the location of each wild coffee species and determining, based on plant population and habitat, which are at risk of extinction. Sixty per cent were found to be threatened, and some may already be lost.

Sources: Science Advances (2019) doi.org/10. 1126/sciadv.aav3473 \& Science Magazine (2019) sciencemag.org/news/2019/o1/ coffee-crisis-6o-wild-species-could-goextinct-some-within-decades

\section{Machine learning tool helps prioritize plants for conservation}

The conservation status of most plant species is unknown, despite their fundamental role in ecosystem health. In a global plant conservation assessment, a multiinstitutional research team used the power of open access databases and machine learning to predict the conservation status of $>150,000$ plant species. They paired geographical, environmental, climatic and morphological trait information of plant species with a known extinction risk from the IUCN Red List with information on plants of unknown risk in a machine learning model. The model calculated the likelihood that a given unassessed plant species was at risk of extinction and identified the variables that best predicted extinction risk. More than 15,000 species, c. $10 \%$ of the total assessed by the team, had characteristics similar to those already categorized as at least Near Threatened and thus at a high likelihood of extinction. The protocol could help identify unassessed species that are potentially threatened, facilitating efficient allocation of scarce conservation resources.

Source: Proceedings of the National Academy of Sciences of the United States of America (2019) doi.org/10.1073/pnas. 1804098115 


\section{INTERNATIONAL}

\section{Plastic chemicals discovered in bird eggs from remote Arctic. .}

Chemicals from plastics have been found inside the eggs of seabirds living in remote Arctic colonies. Scientists were concerned by the traces of phthalates, hormonedisrupting chemicals that have been banned from children's toys because of their potential so-called gender-bending effects. These substances are routinely applied to many plastic products, and probably came from the bottle tops and cigarette butts these seabirds often ingest because they mistake them for food. Consumed plastic items are often too big to pass through the birds' digestive systems, meaning they remain in their stomachs, leaching out chemicals which can pass into developing eggs. The eggs were taken from northern fulmars living on an island in Lancaster Sound, $>160 \mathrm{~km}$ from the nearest human settlement. A preliminary study by the Canadian Wildlife Service tested the eggs of five fulmars and found phthalates in one, but warned the problem is likely to be far more pervasive.

Source: The Independent (2019) indepen dent.co.uk/environment/plastic-bird-eggspollution-arctic-ocean-chemicals-phthalates-research-a8783061.html

\section{... and call for global action on plastic pollution}

A joint position paper on tackling plastic waste for the benefit human health and marine biodiversity has been published by Fauna \& Flora International in collaboration with the Institute of Development Studies, TearFund and WasteAid. The paper sets out why plastic pollution poses particular problems for lower-income countries and highlights the drivers, both proximate and ultimate, for the plastic waste and pollution crisis in the developing world. It also highlights the need for higher-income countries and multinational companies to take responsibility for their role in creating this crisis. Recommendations to help remedy these issues include actions by multinational corporations to ensure sustainable use of plastics in their products. Companies also need to take financial responsibility for the management of postconsumer plastic waste in lower-income countries. International development aid should be aimed at preventing plastic waste generation and pollution, and governments of higher-income countries are called upon to minimize exports of domestic waste.
Source: Fauna \& Flora International (2019) live-fauna-flora-international.pantheonsite.io/wp-content/uploads/2019/o3/FFI_ 2019_Tackling_Plastic_Waste_Pollution_ Human_Health_Marine_Biodiversity.pdf

\section{Why the zebra got its stripes}

The mystery of why the zebra got its stripes may have been solved: researchers say the pattern appears to confuse flies, discouraging them from touching down for a bite. The study involved horses, zebras and horses dressed as zebras. The team said the research not only supported previous work suggesting stripes may act as an insect deterrent, but helped unpick why, revealing the patterns only produced an effect when the flies got close. Researchers made their discovery by noting how horseflies interacted with nine horses and three zebras. Although horseflies circled or touched the animals at similar rates, landing was a different matter, with a lower rate seen for zebras than horses. The team said the study showed stripes did not act as a long-range deterrent but had an effect when the flies got up close, possibly because of the flies' low-resolution vision.

Sources: PLOS ONE (2019) doi.org/10.1371/ journal.pone.0210831, \& The Guardian

(2019) theguardian.com/science/2019/feb/ 20/why-the-zebra-got-its-stripes-to-deterflies-from-landing-on-it

\section{Fish stocks continue to fall as oceans warm. .}

Fish catches have declined markedly and are likely to fall further as ocean temperatures continue to rise. Overall, catches of commercially important fish have fallen by just over $4 \%$, but in some regions catches have plunged by $c$. one-third since the early 190os. Researchers used backcasting methods to reconstruct the effects of global warming, overfishing and other impacts on fisheries over the 80-year period from 1930 to 2010 . They examined 38 regions, studying 235 fish populations of 124 species; i.e. a third of the global fishing catch over the study period. Changes in temperature had an important effect, along with overfishing and ocean acidification. The greatest losses were of fish in the North Sea near the UK, the Sea of Japan, around the Iberian coast and the Celtic-Biscay shelf. There were gains among fish populations in the Labrador-Newfoundland region, the Baltic Sea, the Indian Ocean and the north-east US shelf

Sources: Science (2019) doi.org/10.1126/science.aau1758, \& The Guardian (2019) theguardian.com/environment/2019/feb/28/ fish-stocks-continuing-to-fall-as-oceanswarm-study-finds

\section{and killer whales moving northward into the Pacific Arctic}

Until recently, killer whales Orcinus orca were rarely sighted in the northern reaches of the Pacific Arctic. Although a cosmopoli$\tan$ species, they typically only ventured into the Chukchi Sea between Siberia and Alaska during late July-early August. A new study reports acoustic recordings of killer whales in the area as early as 1 June and as late as 16 November. The percentage of days when their calls were detected in the southern Chukchi Sea from September to November increased from c. $10 \%$ in 2009 to c. $30 \%$ in 2015 . Killer whales rarely migrate into areas with lots of ice, and in the past the sea surface would have been frozen for much of the year. Previous research from Canada's Hudson Bay suggests the arrival of a new apex predator into other northern ecosystems can negatively affect existing populations of marine mammals, which in the Chukchi Sea includes walruses, belugas and bowhead whales.

Sources: Marine Mammal Science (2018) doi.org/10.1111/mms.12551, \& Science Magazine (2019) sciencemag.org/news/ 2019/o1/killer-whales-are-moving-northward-pacific-arctic-possibly-spellingtrouble-local

\section{Seven new calves born to Endangered North Atlantic right whales}

With a long history of exploitation and extremely limited recovery over the past century, the Endangered North Atlantic right whale Eubalena glacialis population continues to decline. In the previous two breeding seasons a total of only five new calves were born to an estimated population of 450 remaining individuals. This year has seen an improvement, however, with seven newborn calves recorded by March 2019, including one born to a first-time mother. This number is nevertheless not high enough to reverse the species' decline: the whales would need to produce $16-18$ calves per year to maintain their present population. Although healthy females typically have calves every 3-4 years, scientists have recorded gaps as long as 9 or 10 years between births for many individuals. The likely drivers of the low birth rate include a lack of food in addition to elevated stress levels as a result of vessel collisions, seismic airgun blasts, and entanglement in fishing gear. Source: The Scientist (2019) the-scientist. com/news-opinion/seven-north-atlanticright-whale-calves-spotted-so-far-thisyear-65561 


\section{Identification of high-priority islands for mammal eradication projects}

In the last 5 centuries, invasive species have been the main driver of extinction of insular species, amounting to $75 \%$ of the loss of terrestrial vertebrates. Researchers have now conducted a feasibility study to identify target islands hosting highly threatened species where the eradication of invasive mammals should be prioritized. Considering ecological and socio-political factors, such as extinction risk and technical feasibility, researchers found that in 169 of the 1,279 analysed islands eradication measures could be implemented within the next decade to improve the survival chance of 111 insular vertebrates. In 107 of these islands such projects could start by 2020 , potentially benefiting 80 threatened species. Given the high success rate of mammal eradication projects worldwide, this work could support conservationists and decision-makers by providing fundamental information needed to target interventions at the locations where they will deliver the greatest benefits for native biodiversity.

Sources: PLOS ONE (2019) doi.org/10.1371/ journal.pone.0212128, \& Mongabay (2019) news.mongabay.com/2019/o4/to-stopextinctions-start-with-these-169-islandsnew-study-finds

\section{Fungus has wiped out more species than any other disease. .}

A lethal kind of chytrid fungus, Batrachochytrium dendrobatidis, has caused the extinction of 90 amphibian species globally, with at least another 491 in decline because of the disease. The fungus is highly infectious, destroying the skin and triggering heart attacks in contaminated individuals. It may be impossible to eradicate, as some amphibious species are immune to its effect and act as a natural reservoir for the pathogen. Although the effects of $B$. dendrobatidis were first noticed in the late 1980s, the extent of the devastation was unknown until recently. Researchers have found that Australia and the Americas have been hardest hit. Populations of 124 species have been reduced by $90 \%$ or more, with the greatest losses amongst frogs. The team has warned of potential effects on global biodiversity as the fungus could soon spread to places that have thus far gone unaffected, such as Madagascar.

Source: Science Magazine (2019) sciencemag.org/news/2019/o3/fungus-has-wipedout-more-species-any-other-disease

\section{... and killing of large species is pushing them towards extinction}

The vast majority of the world's largest animal species are being pushed towards extinction, and although habitat loss, pollution and other factors pose a significant threat to them, intentional and unintentional trapping, poaching and slaughter are the main contributors to their decline. An analysis of 362 megafauna species found that $70 \%$ are declining, with $59 \%$ categorized as threatened on the IUCN Red List. Direct killing by humans is the leading cause of decreasing populations across all classes of animals; other threats include intensive agriculture, toxins and invasive species. The data adds to the mounting evidence that humans are causing a sixth mass extinction event. Many imposing creatures such as rhinos, sharks and tigers perform an important ecological role as apex predators or by spreading seeds. Minimizing the direct killing of the world's largest vertebrates is a priority conservation strategy that could save many of these iconic species and the ecosystem services they provide. Sources: Conservation Letters (2019) doi. org/10.1111/conl.12627, \& The Guardian (2019) theguardian.com/world/2019/feb/ o6/the-killing-of-large-species-is-pushingthem-towards-extinction-study-finds

\section{Technology update: drones and big data could boost conservation. .}

The British International Education Association and the Born Free Foundation hosted a conference in London in January 2019 to highlight the increasing role played by new technologies in conservation and ecology research. New tools need to be cheap, robust and simple to use, so that communities everywhere can employ them to inform conservation planning and management. Much remains to be done to train ecologists in these new methods: camera trapping and acoustic monitoring are commonly featured in biology and conservation degrees, but teaching on how to exploit emerging technologies such as drones is patchy. Other barriers include the limited number of ecologists able to code algorithms specifically for their research problem, slowing the spread of new techniques. Similarly, big data is a valuable tool in the fight against extinction, but must be used to prompt real change if it is to have an impact.

Source: The Guardian (2019) theguardian. $\mathrm{com} /$ education/2019/feb/18/drones-andbig-data-the-next-frontier-in-the-fightagainst-wildlife-extinction
... new sequencing method for small DNA fragments. .

Efforts of wildlife detectives aiming to protect threatened species have long been hindered by the near impossibility of collecting DNA samples from rare and elusive animals. But researchers have now developed a method for extracting genetic clues quickly and cheaply from degraded and other poor quality materials, such as faeces, skin or saliva, and from food products suspected of containing parts of threatened animals. The researchers looked at wild tigers in India and overfished Caribbean queen conchs, examining tiger faeces, shed hair and saliva found on killed prey, and conch fritters purchased in restaurants in the USA. All samples were too impure or degraded for conventional genetic analysis. The team improvised a new approach, using a sequencing method that amplifies and reads small bits of DNA with unique differences in each sample. The technology proved highly effective at identifying and comparing genetic characteristics. Source: Methods in Ecology and Evolution (2019) doi.org/10.1111/2041-210X.13173

\section{... and increasing accuracy of mathematical models vital for predicting extinction}

A study investigating the diversity of population responses to environmental change has highlighted the need to understand changes in survival rates at different life stages of a species, to produce more reliable population models. Survival and reproductive rates vary in individuals as they age, and each species has a particular trend associated with each life stages; ignoring these differences can distort the population's predicted growth rate and our understanding of its extinction risk. The study also underlined the importance of considering trade-offs between survival and reproduction. A good year for reproduction may result in a bad year for survival, as more effort invested in reproducing could mean less energy for upkeep. Despite increasing evidence of these tradeoffs in nature, models don't consistently take them into account. With more sophisticated tailoring, models will improve their capacity to anticipate the impacts of problems such as climate change, invasive species and habitat loss.

Source: The Conversation (2019)

theconversation.com/endangered-speciescould-be-saved-from-extinction-bymathematical-models-heres-how110522 


\section{EUROPE}

\section{Germany's wolves are on the rise thanks to the military}

There is a history of persecuting the grey wolf Canis lupus in western Europe, where it was largely eradicated in the 19th century. However, since the 199os Germany has witnessed a return of the species, and a recent study has shown that populations are growing by $36 \%$ per year. Unexpectedly, military bases play a role in helping wolves reclaim habitat, to a greater extent than civilian nature reserves: wolf mortality rates were lower in military training grounds than in protected areas. Although military training grounds are not fenced, they are closed to the public, limiting access for potential poachers. And because they are managed by federal foresters, hunting is strictly regulated. This reduces conflicts with wolves, who appear to seek out military training areas. Researchers recommend the strict hunting management for such areas should continue after the sites become decommissioned, to preserve their conservation function.

Source: Science Magazine (2019) science mag.org/news/2019/o2/germany-s-wolvesare-rise-thanks-surprising-ally-military

\section{Beavers become protected species in Scotland}

Beavers became a protected species in Scotland in May 2019. The long-awaited and controversial move, opposed by many farmers, followed extensive wrangling over how their numbers should be managed. Farming leaders have raised concerns about the damage caused to agricultural land by beaver dams. Beavers have been extinct in Scotland for 400 years but were illegally released into the wild in Tayside several years ago. The latest count found the population had tripled over 6 years to 430 beavers in more than 100 active territories. Since May 2019 it is an offence to kill, injure or capture the animals. The Scottish Wildlife Trust had been concerned about the lack of protection for beavers while a final decision was awaited. According to the environment secretary, protection and mitigation measures for farmers, particularly around Tayside, will be extensive, and there will be control measures to manage the beaver population.

Source: BBC (2019) bbc.co.uk/news/ukscotland- 47337724

\section{Angel sharks sighted along Welsh coast}

Scientists studying angel sharks Squatina squatina off the coast of the Canary
Islands have discovered that this rare shark species may also be flourishing in Welsh waters. Angel sharks used to be abundant across the east Atlantic and Mediterranean but owing to a number of threats populations have declined in recent years. Categorized as Critically Endangered on the IUCN Red List, an increase in angel shark sightings could indicate that the waters around Wales are a key habitat for the species. Recent records of angel sharks off the coast of Wales have caused scientists to question whether the sharks are moving between Wales and the Canary Islands or whether the populations are distinct. Genetic research using swabs taken from a shark's skin could give the answer, and dives are planned for later in the year, to look for direct evidence of angel sharks. Source: BBC (2019) bbc.co.uk/news/ science-environment-46972070

\section{Microplastics found in every marine mammal surveyed in UK study}

Microplastics are being widely ingested by Britain's marine mammals, with samples found in every animal examined in a recent study. Research on 50 stranded creatures, including porpoises, dolphins, grey seals and a pygmy sperm whale, is the most comprehensive analysis of microplastics in the digestive tracts of both wild cetaceans and seals. The study found that nylon comprised $>60 \%$ of the microplastics, with possible sources including fishing rope and nets, clothing microfibres and toothbrush bristles. Polyethylene terephthalate and polyester were also widely present. As well as accidental consumption, microplastics are ingested indirectly when predators consume contaminated prey such as fish. On average, 5.5 particles were found in the guts of each animal, suggesting they pass through the digestive system, or are regurgitated. The researchers are concerned that long-term exposure to plastic pollution could damage the health of Britain's marine mammals.

Sources: Scientific Reports (2019) doi.org/10. 1038/s41598-018-37428-3, \& The Guardian (2019) theguardian.com/environment/ 2019/jan/31/microplastics-found-everymarine-mammal-uk-study

\section{NORTH EURASIA}

\section{Rewilding in Belarus: Dutch Konik ponies to move to Naliboki Reserve}

Belarus' Forestry Ministry and the State Forest Service of the Netherlands have begun a cooperation in environmental protection, with a transfer of wild horses to Belarus set to become the first major joint effort. Rewilding, a progressive approach to conservation that aims to restore natural processes by reintroducing keystone species, is at the heart of the project. More than 50 konik ponies from Oostvaardersplassen nature reserve will be transferred to Belarus in the summer, reducing the number of large mammals on the Dutch reserve. Deer, cattle and wild horses were introduced to the reserve c. 30 years ago to help preserve open landscapes and habitats for wetland birds, but their increasing numbers led to a mass starvation in the 2017-2018 winter. The ponies' new home, the 86,892 ha Naliboki Reserve, is in the west of Belarus in Naliboki Forest, one of the biggest forests in the country and in Eastern Europe. Sources: Belarus News (2019) eng.belta.by/ society/view/netherlands-to-give-over-50wild-horses-to-belarus-119728-2019, \& Dutch News (2019) dutchnews.nl/news/ 2019/03/dutch-reserve-ponies-found-newhomes-in-spain-and-belarus

\section{Saiga ranger's death sparks Kazakh call for justice}

January 2019 saw the first time in the history of Okhotzooprom, the agency that protects Kazakhstan's wildlife, that poachers have killed a state ranger. Mr Nurgaliev's death caused a huge outcry, with many people urging authorities not to let the criminals get away with this murder. The poachers who escaped were hunting saiga Saiga tatarica. Kazakhstan is home to the largest population of saiga and it is a criminal offense to hunt the species there. Poaching was one of the main reasons why their population dropped from more than one million in the early 1990 s to c. 20,000 a decade later. Thanks to conservation projects and antipoaching measures, the saiga population in Kazakhstan has increased to c. 200,000. Kazakh authorities say that they will find the perpetrators, to discourage future poaching.

Source: BBC (2019) bbc.co.uk/news/worldasia-46925699

NORTH AFRICA AND MIDDLE EAST

New Arabic mobile app celebrates bird diversity in the Middle East

According to BirdLife International, some two million birds migrate through the Middle East each autumn, but it is 
estimated up to a quarter of them are shot or trapped by hunters every year. Numerous species from Europe, Central Asia, Siberia and the Arctic travel through a flyway in the Middle East on their way to East and Southern Africa, making the region an important stopover. A region-wide effort seeks to change attitudes to wildlife and engage a younger, technologicallyminded demographic through a new fieldguide app, the world's first to be launched fully in Arabic. The free app was created by a conservation charity, based on the book Birds of the Middle East. It features pictures, descriptions of behaviour and samples of bird song, and has already been downloaded several thousand times. The developers hope to introduce the app's content in the national curriculum, for use as a structured educational tool. Source: Gulf News (2019) gulfnews.com/ uae/environment/uae-could-be-a-hotspotfor-bird-lovers-1.61923276

\section{SUB-SAHARAN AFRICA}

\section{Chimpanzee declared national icon in Sierra Leone. .}

In February 2019 Sierra Leone declared the Critically Endangered western chimpanzee Pan troglodytes subsp. verus the national animal and vowed to protect the species from anthropogenic threats. The declaration was made in honour of a visit by Jane Goodall, eminent primatologist, anthropologist and UN Messenger of Peace. Goodall was instrumental in setting up Tacugama Reserve, the only chimpanzee sanctuary in the country, 27 years previously. The chimpanzee population declined by $>80 \%$ during 1990-2014, and Sierra Leone is home to $10 \%$ of c. 55,000 individuals still living in the wild. Chimpanzees are threatened by poaching, retaliatory killings in response to crop use and habitat loss to urban development and forestry. During the declaration ceremony the head of the sanctuary, Bala Amarasekaran, urged the government to unite all stakeholders to protect the chimpanzees' habitat from deforestation and other harmful activities, and to review wildlife and biodiversity laws to ensure long-term protection. Source: Awoko (2019) awoko.org/2019/03/ 05/sierra-leone-news-chimpanzeedeclared-national-icon

\section{human activities are interfering with chimpanzee culture...}

As human activities continue to expand into previously wild areas in central and western Africa, chimpanzee populations are not only reduced in size, but the animals' unique behavioral traditions also become depleted. During a 10-year study, scientists observed 144 chimpanzee groups in 15 countries throughout the species' range and found specific behaviours in different subpopulations, such as fishing for algae, cracking nuts, throwing stones and certain methods for hunting or termite harvesting. These distinct behaviours are passed between generations but drop by as much as $88 \%$ for chimpanzees living near humans. The researchers call for preservation of the animals' behavioural diversity along with the species itself, suggesting that locations with exceptional sets of behaviours should be protected as chimpanzee cultural heritage sites. This concept could also be extended to other species with a high degree of cultural variability, including orangutans, capuchin monkeys and whales. Sources: Science (2019) doi.org/10.1126/ science.aau4532, \& USA Today (2019) eu. usatoday.com/story/news/nation/2019/03/ o7/chimps-culture-ruined-by-humanactivity-study/3094395002

\section{. and Chinese dam project in Guinea could kill up to 1,500 chimpanzees}

Up to 1,500 chimpanzees could be killed by a new dam that will swamp a crucial sanctuary for chimpanzees in Guinea. The 294 MW Koukoutamba dam will be built by Sinohydro, the world's biggest hydroelectric power plant construction company, in the middle of a newly declared protected area called the Moyen-Bafing National Park. The Chinese company is already facing similar criticism for building a dam in Indonesia that threatens the only known habitat of a newly discovered species of orangutan. Its executives signed a contract this week with local representatives eager to secure a power project that will bring energy and funds to one of Africa's poorest countries. The flooding of swathes of the Park is expected to force the displacement of 8,700 people. It will also increase the pressure on western chimpanzees, which have declined by $80 \%$ in the past 20 years, and are now considered Critically Endangered.

Source: The Guardian (2019) theguardian. com/world/2019/feb/28/chinese-damproject-in-guinea-could-kill-up-to-150ochimpanzees

\section{Botswana mulls lifting elephant hunting ban}

Shortly after coming into office in April 2018, Botswana's President Mokgweetsi Masisi asked ministers to review the hunting ban implemented by his predecessor Ian Khama in 2014. The report's findings recommend that: the hunting ban should be lifted; the elephant population should be managed within its historic range; wildlife migratory routes not beneficial to the country's conservation efforts should be closed; game ranches be demarcated to serve as buffers between communal and wildlife areas; and regular but limited elephant culling should be introduced. The report which will go through further consultation before being implemented. The number of elephants in Botswana is estimated to be c. 130,00o, which some argue is too many for the ecosystem, and there is increasing conflict between wildlife and people. Others say the country's tourism has grown dramatically since the ban came into place and that lifting it would affect the country's international reputation for conservation.

Source: BBC (2019) bbc.co.uk/news/worldafrica-47330414

\section{Search for sodium a risky business for Rwanda's gorillas}

Despite their Endangered status, the mountain gorillas Gorilla beringei beringei of Uganda, The Democratic Republic of the Congo and Rwanda are often heralded as a conservation success, having recently been down-listed from Critically Endangered because the population is increasing. In the Volcanoes National Park, Rwanda, the gorillas occasionally leave the protected area and use crops, which puts them into conflict with local communities. Researchers studying the apes' diet identified that the crop-using behaviour may be driven by a quest for sodium, a vital mineral. The gorillas' common food plants are relatively sodium-poor, and some groups obtain over two-thirds of their sodium requirements from eating eucalyptus tree bark in nearby plantations. Before the development of these plantations, gorillas may have ventured into the subalpine and alpine zones of the Virunga mountains to find sodium-rich plants, which is also risky as it exposes the animals to low temperatures that could cause hypothermia.

Sources: Biotropica (2018) doi.org/10.1111/ btp.12598, \& Mongabay (2019) news. mongabay.com/2019/03/salt-fiends-searchfor-sodium-puts-rwandas-gorillas-inharms-way

\section{Tanzania court sentences Chinese 'Ivory Queen' to 15 years prison}

A Chinese businesswoman labelled the Ivory Queen has been sentenced to 15 
years in prison by a Tanzanian judge for smuggling the tusks of more than 350 elephants. Yang Feng Glan, 69, had been charged in October 2015, along with two Tanzanian men, with smuggling c. 860 pieces of ivory worth USD 5.6 million, over several years, to Asia. On 19 February 2019 Kisutu Court Magistrate Huruma Shaidi handed the trio 15-year sentences following their convictions for leading an organized criminal gang. All three had denied the charges. Shaidi also ordered them to either pay twice the market value of the elephant tusks or face an additional 2 years in prison. Police sources said Yang had lived in Tanzania since the 1970 and was secretary-general of the Tanzania China-Africa Business Council. Conservationists welcomed Yang's conviction, saying it was proof of the government's seriousness in the fight against wildlife poaching.

Source: Aljazeera (2019) aljazeera.com/ news/2019/o2/tanzania-court-sentenceschinese-ivory-queen-15-years-prison190220030633305.html

\section{SOUTH AND SOUTH-EAST ASIA}

\section{Description of new tarantula species legally questionable. .}

The female of a newly described species of tarantula, Birupes simoroxigorum, has electric-blue legs and a creamy toffee body. Native to the state of Sarawak in Malaysia, the burrow-dwelling species was first photographed in the wild in 2017 and formally described by arachnologists from Oxford, UK, in early 2019. But the two specimens used to describe the species may have been collected and exported from Malaysia illegally, in what has been described as a case of bio-piracy. Although the researchers said they received the specimens in good faith and were told they were legally collected with all appropriate paperwork, one of the collectors has since admitted they did not have permits for collection, stating they did not know permits were required. Individuals of the species have since been advertised for sale online. Illegal tarantula trade is a burgeoning problem, with collectors that previously favored Brazil and Mexico now shifting to South-east Asia.

Source: Science Magazine (2019) sciencemag.org/news/2019/o2/amazing-blue-tarantula-new-spider-species-did-researchers-break-law-when-they-studied
... and new mysterious frog species
discovered in India's Western Ghats

Researchers from Delhi University found a new species of frog in the Western Ghats, a biodiversity hotspot in southern India. The species belongs to a new frog genus that the scientists have named Mysticellus, derived from Latin meaning mysterious and diminutive. This frog probably went unnoticed previously because it appears for less than 4 days per year, for breeding activities, and lives a secretive lifestyle for the rest of the year. Indian amphibians face various threats, particularly habitat loss and degradation. The only known population of the new genus occurs in a wayside area disturbed by vehicular movement, plantation activities and human settlements. Because little is known about the species' habitat requirements and range, the site needs to be preserved to protect the species.

Source: $B B C$ (2019) bbc.co.uk/news/worldasia-india-47208169

\section{Tiger geckos in Viet Nam could be the next species sold into extinction}

Although information about the conservation status of tiger geckos of the genus Goniurosaurus is largely absent, these Asian lizards are already vulnerable to extinction. They have been facing severe declines over the last 2 decades, mostly because of overcollection for the international exotic pet market. A study has now provided an overview of domestic and international trade in this genus, with a focus on species native to Viet Nam. The researchers tracked local traders in possession of wild-caught tiger geckos representing all five Vietnamese species, en route to foreign exotic pet markets, mainly in the USA, the EU and Japan. The animals were also frequently sold in local pet shops in Viet $\mathrm{Nam}$, and offered via various online platforms and social media networks. Providing further knowledge about the species' abundance and the threats to tiger geckos, the research team urged authorities to implement strict conservation measures. Sources: Nature Conservation (2019) doi. org/10.3897/natureconservation.32.33590, \& Science Daily (2019) sciencedaily.com/ releases/2019/04/190401115818.htm

\section{Seizure of $14 t$ of pangolin scales in Singapore sets a dismal record}

In April, Singapore discovered more than $14 \mathrm{t}$ of pangolin scales in what may be the largest seizure of a single shipment, highlighting the persistence of illegal trade in the scaly anteater. Circa 36,000 pangolins will have been killed for the shipment. Pangolins are believed to be the most illegally trafficked mammal, with an estimated 300 poached per day. Singaporean customs officials and the country's national parks board said in a statement that the scales, which had been shipped from Nigeria, were bound for Viet Nam, home to the second-most lucrative black market for pangolin scales after China. International laws forbid trade of all pangolin species, and techniques such as fingerprint forensics seek to deter poachers, but recent seizures have shown that pangolins are still heavily trafficked around the world.

Source: New York Times (2019) nytimes. com/2019/04/o8/world/asia/pangolinsingapore-seizure-poaching.html

\section{World's largest bee, missing for 38 years, found in Indonesia}

Having been feared extinct for 38 years, the world's largest bee has been rediscovered on the Indonesian islands of the North Moluccas. A team of biologists found a single female Wallace's giant bee Megachile pluto living inside a termites' nest in a tree. The giant bee-females can measure nearly $4 \mathrm{~cm}$ in length-was first found in 1858 when Alfred Russel Wallace discovered it on the tropical Indonesian island of Bacan. He described the female bee as 'a large, black, wasp-like insect, with immense jaws like a stag beetle'. Despite its size, the bee remained elusive, with almost nothing known about the female's secretive life cycle, which involves making nests of tree resin inside active arboreal termite mounds. The bee was not seen again by scientists until 1981. Search teams failed to find it subsequently, but the rediscovery of a sole female raises hopes that the region's forests still harbour this species.

Source: The Guardian (2019) theguardian. com/environment/2019/feb/21/worlds-

largest-bee-missing-for-38-years-found-inindonesia

\section{EAST ASIA}

\section{Poaching of Endangered snow leopards increases in Mongolia}

Poaching of Endangered snow leopards is increasing in Mongolia, possibly because their bones may be used as substitutes for those of tigers in Traditional Asian Medicine markets. Previously, the country recorded one or two such cases per year, connected with the snow leopard fur trade. The recent rise in illegal hunting of this elusive felid in Mongolia may be related 
to increased tiger conservation efforts in all tiger range countries. Conflict between local herders and snow leopards is another concern. Experts have been taking various measures to handle the conflict, including asking local herders to hand in traps in exchange for household utensils. WWF conservation experts are working in Mongolia to determine the population and distribution of snow leopards, and explore ways to protect them. It is estimated that only $800-$ 1,200 snow leopards remain in the country. Source: XinhuaNet (2019) xinhuanet.com/ english/2019-03/22/c_137915553.htm

\section{Supposedly extinct Formosan clouded leopard spotted in Taiwan}

The Formosan clouded leopard Neofelis nebulosa brachyura, thought to be extinct, has reportedly been seen by several witnesses in south-east Taiwan. Alangyi Village rangers recently spotted what they believed to be a Formosan clouded leopard hunting goats on a cliff in Taitung County's Daren Township. As a result of the sightings of the sacred animal, the Alangyi Village held a tribal meeting to further investigate the sightings and to prohibit outsiders from hunting in the area. Alangyi Village elders also asked the Forestry Bureau to halt logging and other disruptive activities. The only non-Indigenous person to ever witness this felid was Japanese anthropologist Torii Ryūzō, in 1900. The last confirmed sighting of the species was in 1983. A long-term survey carried out by a team of zoologists from Taiwan and the USA during 2001-2013 failed to yield a single sighting of the elusive animal, prompting scientists to declare it officially extinct in 2013 (see also Oryx, 49, 261-269). Source: Taiwan News (2019) taiwannews. com.tw/en/news/3644433

\section{NORTH AMERICA}

\section{Elephant seals take over beach left vacant by US shutdown}

In winter 2018, during the Trump government shutdown, US parks and wildlife areas such as northern California's Point Reyes National Seashore were unstaffed for 35 days. With no rangers to discourage their coming ashore, 100 female Elephant seals claimed the unexpectedly vacant Drake's Beach as a temporary home. The giant seals were hunted nearly to extinction in California but have staged a comeback thanks to conservation initiatives. The park has declared the beach off-limits and closed the access road, allowing the 100 pups to nurse in peace under the watchful eye of a handful of three-ton males. As the pups got older, rangers conducted carefully guided tours for park visitors to observe the seal colony from a safe distance, and it was decided that the seals would be allowed to stay until they naturally decided to move on.

Source: The Guardian (2019) theguardian. com/environment/2019/feb/o2/elephantseals-california-shutdown-drakes-beach

\section{Salmon diversity crucial to thriving Canadian coastal bear populations. .}

Researchers have found it is beneficial for coastal black bears to eat a number of different salmon species because their migration runs are spread out over the year. A given amount of biomass spread across four salmon species allowed black bears to consume c. three times more fish per year than the same biomass from one large run of a single species. The team tested hair samples from 379 black bears and 122 grizzly bears in British Columbia's Great Bear Rainforest, Canada, to estimate salmon consumption, a measure that relates to the number of cubs produced, body size and population density. Their simulation estimated that adding two species of salmon to a river that naturally hosts only two species resulted in a $3 \%$ rise in biomass. However, the number of days that salmon would be vulnerable to predation increased by $30 \%$, and the number of fishable days increased by $60 \%$. The team hope their findings will prompt federal authorities to think more broadly about fish conservation. Sources: Journal of Animal Ecology (2019) doi.org/10.1111/1365-2656.12932, \& The Globe and Mail (2019) theglobeandmail. com/canada/british-columbia/articlesalmon-diversity-crucial-to-thriving-coastalbear-populations-bc

\section{... and California sea lions culled to protect threatened salmon}

Oregon's Columbia River is home to threatened species of chinook and steelhead salmon that feed in the Pacific Ocean before returning up river to spawn. Over the past decade increasing numbers of California sea lions have gorged on these fish gathered at man-made fish ladders, designed to help salmon climb to better habitat. Safeguarded by the Marine Mammal Protection Act, the California Sea lion population has grown to more than 250,000 in 2018 . In contrast, salmon numbers have dwindled. Through the federal Endangered Species Act, Oregon Department of Fish and Wildlife authorities obtained a permit to cull up to 92 sea lions per year, but humane societies have protested. California Marine biologists are actively engaged with Oregon officials to explore other options. This is another striking example of the ways in which human intervention leads to an out-of-balance ecosystem. Source: San Francisco Chronicle (2019) sfchronicle.com/news/article/Oregonbiologists-killing-California-sea-lions-to13565785.php

\section{The contiguous United States has lost its last wild caribou}

The last caribou known to inhabit the contiguous USA has been removed from the wild. In January 2019 a team of Canadian biologists captured the caribou in the Selkirk Mountains just north of the USACanada border. The female caribou is believed to be the last member of the last herd to regularly cross into the lower 48 states from Canada. Despite plans to release the caribou, along with two other animals from another herd, their fate remains unclear. They are mountain caribou, a distinct ecotype found only in a forested swath of northwestern North America, which have become threatened because of habitat loss and other factors. Conservation efforts have failed to reverse population declines or prevent the complete extirpation of some herds at the southern end of the mountain caribou's range. Conservationists also fear removing caribou from the wild will ultimately lead to the lifting of protections for its habitat, especially if the animals never return.

Source: Science Magazine (2019) science mag.org/news/2019/o1/contiguous-unitedstates-just-lost-its-last-wild-caribou

\section{CENTRAL AMERICA AND} CARIBBEAN

\section{Barbados bans single use petroleum-based plastics}

As of April 2019 the import, retail, sale and use of petroleum-based single-use plastic is no longer allowed in Barbados. Products such as single-use plastic cups, cutlery, including plastic knives, forks and spoons, stirrers, straws, plates, egg trays and Styrofoam containers used in the culinary retail industry will be banned. In a joint press conference, Minister of Maritime Affairs and the Blue Economy, Kirk Humphrey, and Minister of the Environment and National Beautification, Trevor Prescod, announced the ban, and its parameters. The decision came after months of consultation with stakeholders, including plastic bag manufacturers, the poultry industry, the Barbados Manufacturers' Association, the Barbados Chamber of Commerce and Industry, the 
Customs Department, and importers. From 2020 all petroleum-based plastic bags will also be banned, giving time to allow manufacturers to devise alternative ways of making plastic bags from a bio-based material that is more environmentally friendly.

Source: Carve Surfing Magazine (2019) carvemag.com/2019/o1/barbados-banssingle-use-petro-based-plastics

\section{Wildlife traffickers thrive on} Guatemala's murky border with Belize A long-running border dispute between Guatemala and Belize has left authorities and environmentalists struggling to combat the extensive illegal trade in wild animal and plant species. Guatemala's environmental prosecutor has highlighted the existence of complex criminal structures operating within the zone between the two countries, where security patrols struggle to identify exactly where the border falls, and legislation designed to curb deforestation is openly flouted. Common targets for extraction include parrots and macaws destined for the black market, as well as ornamental palms and CITES-listed rosewood Dalbergia tucurensis. Authorities point to the involvement of local farmers and forest communities, enticed into illegal trapping and logging by traffickers, who go on to work with intermediaries from both countries, corrupt public officials, and financiers from Asia. The problem is compounded by political uncertainty and widespread poverty, making involvement in the trapping, smuggling and sale of protected species an attractive option for people struggling to find sustainable livelihoods.

Source: Mongabay (2019) news.mongabay. com/2019/03/wildlife-traffickers-thrive-onguatemalas-murky-border-with-belize

\section{Turtles' absence from Nicaraguan stronghold raises alarm}

Every year, during November-March, leatherback sea turtles arrive at the secluded shores of the Río Escalante Chacocente wildlife reserve on Nicaragua's Pacific coast to lay their eggs. Although the nesting habits of leatherback turtles vary, Chacocente has been a reliable egg-laying site for as long as conservationists have collected nesting data. This year, not a single leatherback came to Chacocente, and conservation groups in Costa Rica and Mexico have recorded declines in sightings of these turtles. Leatherback turtle populations face threats from human activities such as poaching and the effects of global warming, and the eastern Pacific population is categorized as Critically Endangered. Fauna \& Flora International estimates that its education and conservation programmes now protect $90 \%$ of Nicaragua's leatherback turtle nests, but this has not been enough to undo historical damage.

Source: The Guardian (2019) theguardian. com/environment/2019/apr/15/leatherbackturtles-nicaragua

\section{SOUTH AMERICA}

\section{Colombian regulations: new hope for biodiversity researchers?}

Many Colombian scientists have become frustrated with the long and complex process of gaining approval from the Ministry of Environment and Sustainable Development, halting a number of research projects into Colombia's extraordinary biodiversity. After facing the slow bureaucracy himself, Jean Paul Delgado initiated a campaign to reform the permit process, which is unnecessarily slow and too often hampers important studies. The recent creation of the nation's first Science Ministry is a sign that the country is becoming increasingly science-friendly, and has been met with cautious optimism in the scientific research community. Although tangible change still requires further action by the Colombian government, there is hope that excessive regulation will be removed, permitting more effective biodiversity research.

Source: Science Magazine (2019) sciencemag. org/news/2019/02/colombia-biodiversityresearchers-seek-relief-regulatory-red-tape

\section{In Galápagos, drones help tackle rat infestation. .}

Drones are helping conservationists rid North Seymour Island, Galápagos, of an infestation of rats that is threatening indigenous birds. The island's rare birds nest on the ground and their numbers are being depleted by the invasion of brown and black rats. The discovery of the infestation in early 2018 prompted action by NGO Island Conservation and the Galápagos Ministry of the Environment to rid the territory of the pest. The drones work much faster and more cheaply than helicopters, which have been used in similar rat eradication projects elsewhere. Each drone was flown for many 15-minute journeys, during which they dispensed c. $20 \mathrm{~kg}$ of poison. The island has few trees so it is difficult for the indigenous birds to escape predation and there are no native species that would prey on rats. If the rats can be eliminated this could herald the return of lava gulls, which no longer nest on North Seymour. Source: BBC (2019) bbc.co.uk/news/ technology-47071513
... and giant tortoise believed extinct for over a century has been found

A living member of a species of tortoise not seen in more than 110 years and feared extinct has been found in a remote part of the Galápagos island of Fernandina. An adult female Chelonoidis phantasticus, also known as the Fernandina giant tortoise, was spotted in February 2019 by a joint expedition of the Galápagos National Park and the US-based Galápagos Conservancy. The team took the tortoise, which is probably $>100$ years old, to a breeding centre for giant tortoises on Santa Cruz Island. The Fernandina giant tortoise is categorized as Critically Endangered, and Possibly Extinct. The only other living member of the species was found in 1906. Since then, expeditions have found tortoise faeces and bite marks on cacti, and there was a possible, but unconfirmed, sighting in 2009. This latest discovery was the first confirmed sighting and has raised hopes that breeding of this rare reptile may be possible if more members of the species can be found. Source: The Guardian (2019) theguardian. com/environment/2019/feb/21/gianttortoise-believed-extinct-for-10o-yearsfound-in-galapagos

\section{PACIFIC}

\section{First successful rat removal project in the Marquesas Archipelago}

Conservationists have carried out the first successful removal of invasive rats on an island in the Marquesas Archipelago, French Polynesia. The project, implemented by the Société d'Ornithologie de Polynésie (Manu), Island Conservation, BirdLife International and Association Vaiku'a i te manu o Ua, will protect a significant population of 90,000 sooty terns and restore habitat for other native seabirds and plants. It also helps to build confidence and capacity within the local community, and to protect the nearby island of Hemeni, an important refuge for seabird populations. Seabirds are critical to a healthy functioning ecosystem because they boost the fertility of island soils. When nutrients from the birds' droppings run off into the marine ecosystem, they enrich the surrounding waters, which results in increased coral productivity and local fish populations. The project partnership will now focus on planning the restoration of the six other uninhabited islands within the Marquesan Archipelago. Source: Island Conservation (2019) island conservation.org/first-successful-rat-removalmarquesas-protects-seabird 


\section{Solomon Islands oil spill sees fuel leak halted}

In February 2019 the Hong Kong-based bulk carrier MV Solomon Trader ran aground off Rennell Island during heavy storms, just a few kilometres from the Kangava Bay UNESCO World Heritage Site. Damage to the ship's fuel tanks led to a leak that continued for over a month and extended c. $6 \mathrm{~km}$ along the island's shoreline because the ship's owner failed to intervene, citing dangerous weather conditions. Teams from the Solomon Islands and Australia successfully stemmed the flow of heavy fuel that had spilled across beaches and into the sensitive coral, but by early April it was still too early to quantify the full extent of the ecological damage and long-term effects. An international cleanup operation is underway, and local communities are dealing with the threat to their food and water security as fishing is suspended and water reserves are low in the wake of limited rainfall on the island. Source: Mongabay (2019) news.mongabay. com/2019/o4/solomon-islands-oil-stopsspilling-but-environmental-toll-still-beingcalculated

\section{AUSTRALIAVANTARCTICAV NEW ZEALAND}

\section{Critically Endangered grey nurse shark mapped for the first time}

A study mapping Critically Endangered grey nurse sharks Carcharias taurus in eastern Australia found the population declined rapidly over the last few decades, with only 400 breeding sharks remaining, too few to maintain a healthy population. Diving with grey nurse sharks is a popular attraction at locations along the east coast of Australia, but the decreasing population puts the industry's future in doubt. The grey nurse shark suffered major declines from overfishing in the 1960 s and 1970 s because they were considered dangerous and are easy to kill, being relatively slow-moving and aggregating in regular areas. This resulted in controversial closures of fishing areas. Despite designated protection areas, the team found that grey nurse sharks tend to disperse out of these areas and are caught as bycatch when travelling between safe zones. Future conservation efforts need to mitigate threats outside protected areas and consider the impact of recreational diving, fishing and the use of shark nets. Source: Phys.org (2019) phys.org/news/ 2019-02-critically-endangered-grey-nurseshark.html

\section{Coal power plant planned in Critically Endangered bird's breeding area}

The site flagged for a 2,00o MW coal-fired power plant in the Hunter region of New South Wales was the only breeding site in the state in 2018 for the regent honeyeater Anthochaera phrygia, a Critically Endangered bird whose plight has blocked previous development plans. An agreement has previously been struck between the China Energy Engineering Corporation, Hong Kong-based Kaisun Holdings and Cavcorp to build a new coal plant. Previous plans to develop land in the Hunter Economic Zone collapsed because of their impact on the land, and particularly on the regent honeyeater. In 2016 the New South Wales Land and Environment Court overturned the approval for a steel plant on the grounds that it would destroy the honeyeater's habitat. In 2018 BirdLife Australia conducted searches for this species (estimated population $<400$ birds) and only observed nesting birds and chicks in the Hunter Economic Zone, thus highlighting the importance of these woodlands. Source: The Guardian (2019) theguardian. com/environment/2019/mar/o7/siteplanned-hunter-coal-plant-is-endangeredbirds-only-nsw-breeding-area

\section{New monitoring approach confirms reintroduction of charismatic New Zealand bird}

Researchers have applied a pioneering method for monitoring the outcome of species translocations, using as a case study the reintroduction of one of New Zealand's rarest birds, the hihi or stichbird Notiomystis cincta, to an area in which it was previously driven to local extinction. The team deployed acoustic recording devices to track the birds, using their distinctive calls (similar to the sound of two marbles clanging together) as a proxy for their movements. The calls were initially randomly distributed but changed to a pattern of more settled home ranges over time. The reintroduction attempt was therefore deemed a success without the need for more invasive physical monitoring, which could potentially alter the behaviour or survival of the translocated individuals. This method shows promise for future reintroduction programmes of species that are difficult to monitor, as it allows researchers to gain a greater understanding of post-translocational movements.

Source: Zoological Society of London (2019) zsl.org/science/news/'eavesdropping'technology-used-to-protect-one-of-newzealand's-rarest-birds

\section{Is the fishing industry leaving enough food for Antarctica's top predators?}

A major research effort led by the Institute of Marine Research in Bergen, Norway, is underway in the Scotia Sea, to map krill abundance in Antarctica. The study will also test tools designed to facilitate cheaper and more frequent surveys, to improve fisheries oversight in the region. The Convention for the Conservation of Antarctic Marine Living Resources sets tight limits on krill fishing, and last conducted a similar survey in 2000. Although that study suggested a healthy population of $c$. 60 million $t$ of krill in the Scotia Sea, regional populations go through boom and bust cycles, making it difficult to identify trends. The expedition aims to measure oceanographic variables to establish whether they can be used to predict krill abundance, and to study interactions between krill fisheries and predators such as seals, penguins and whales. In this way, the project hopes to gain a more nuanced understanding of the complex, dynamic drivers of krill population change, to inform future management decisions.

Source: Science Magazine (2019) science mag.org/news/2019/o1/fishing-industryleaving-enough-food-antarcticas-toppredators

All internet addresses were up to date at time of writing. The Briefly section in this issue was written and compiled by Emma Muench, Julia Hochbach and Martin Fisher, with additional contributions from Duncan Butler, Caroline Kerbyson, Charlie Mack, Filippo Marino, Mike Maunder, Steve Muench, Anna Michieletto SánchezPedreño, Annkathrin Sharp and Tom White. Contributions from authoritative published sources (including websites) are always welcome. Please send contributions by e-mail to oryx@fauna-flora.org. 